\title{
Effects of Folic Acid on Secretases Involved in A $\beta$ Deposition in APP/PS1 Mice
}

\author{
Tian Tian, Dong Bai, Wen Li, Guo-Wei Huang and Huan Liu * \\ Department of Nutrition and Food Science, School of Public Health, Tianjin Medical University, \\ Tianjin 300070, China; tiantiantmu@126.com (T.T.); baidongtmu@126.com (D.B.); \\ liwen828@163.com (W.L.); huangguowei@tmu.edu.cn (G.-W.H.) \\ * Correspondence: liuhuan@tmu.edu.cn; Tel.: +86-22-8333-6615
}

Received: 30 June 2016; Accepted: 6 September 2016; Published: 9 September 2016

\begin{abstract}
Alzheimer's disease (AD) is the most common type of dementia. Amyloid- $\beta$ protein (A $\beta$ ) is identified as the core protein of neuritic plaques. $A \beta$ is generated by the sequential cleavage of the amyloid precursor protein (APP) via the APP cleaving enzyme ( $\alpha$-secretase, or $\beta$-secretase) and $\gamma$-secretase. Previous studies indicated that folate deficiency elevated A $\beta$ deposition in APP/PS1 mice, and this rise was prevented by folic acid. In the present study, we aimed to investigate whether folic acid could influence the generation of $A \beta$ by regulating $\alpha-, \beta-$, and $\gamma$-secretase. Herein, we demonstrated that folic acid reduced the deposition of A $\beta 42$ in APP/PS1 mice brain by decreasing the mRNA and protein expressions of $\beta$-secretase [beta-site APP-cleaving enzyme 1 (BACE1)] and $\gamma$-secretase complex catalytic component-presenilin 1 (PS1)—in APP/PS1 mice brain. Meanwhile, folic acid increased the levels of ADAM9 and ADAM10, which are important $\alpha$-secretases in ADAM (a disintegrin and metalloprotease) family. However, folic acid has no impact on the protein expression of nicastrin (Nct), another component of $\gamma$-secretase complex. Moreover, folic acid regulated the expression of miR-126-3p and miR-339-5p, which target ADAM9 and BACE1, respectively. Taken together, the effect of folic acid on A $\beta$ deposition may relate to making APP metabolism through non-amyloidogenic pathway by decreasing $\beta$-secretase and increasing $\alpha$-secretase. MicroRNA (miRNA) may involve in the regulation mechanism of folic acid on secretase expression.
\end{abstract}

Keywords: Alzheimer's disease; folic acid; $\mathrm{A} \beta$ generation; secretase; microRNAs

\section{Introduction}

Alzheimer's disease (AD) is the most common type of dementia. The most common initial symptom is gradual memory loss followed by impairment of other intellectual abilities. The amyloid- $\beta$ protein $(A \beta)$ was isolated from brains with amyloid deposition and it was subsequently identified as the core protein of neuritic plaques [1,2]. The major constituents of the amyloid plaques are well established and include the $4 \mathrm{kDa} A \beta$ peptides, primarily $\mathrm{A} \beta 42$ and $\mathrm{A} \beta 40$. Reduction in $\mathrm{A} \beta 42$ in prodromal $\mathrm{AD}$ might slow the progression of the disease by affecting the rate of plaque formation [3].

$A \beta$ is derived from amyloid- $\beta$ precursor protein (APP) by sequential proteolytic cleavage. The enzymes in this process are essential for APP processing and A $\beta$ production. Cleavage of APP by $\alpha$-secretase precludes $A \beta$ generation as the cleavage site is within the $A \beta$ domain, and releases a large soluble ectodomain of APP called SAPP $\alpha$ as well as a carboxyl terminal fragments (CTFs) of APP called $\alpha$ CTF. After $\alpha$-cleavage, $\alpha$ CTF will be further cleaved by $\gamma$-secretase to puduce p3 peptides and APP intracellular domain (AICD). The pathway is known as "non-amyloidogenic", since $\alpha$-secretase processing of APP prevents the formation of intact A $\beta$ peptide. The best-studied $\alpha$-secretases were members of the ADAM (a disintegrin and metalloprotease) family, in particular ADAM9 and ADAM10 [4]. 
An alternative route that is particularly present in neurons and brain is known as the "amyloidogenic pathway" which involves cleavage of APP by $\beta$-secretase[beta-site APP-cleaving enzyme 1 (BACE1)]. This cleavage generates a truncated APP secreted form (sAPP $\beta$ ) and a membrane-anchored carboxyterminal fragment of 99 amino acids (C99) that contains the entire A $\beta$ region. C99 is subsequently cleaved by $\gamma$-secretase to generate the $\mathrm{C}$-terminus of the A $\beta$ peptide and AICD [5].

$\gamma$-secretase is a large complex composed of the four polypeptides: presenilin (PS1 or PS2), nicastrin (Nct), presenilin enhancer 2 (Pen2), and anterior pharynxdefective 1 (Aph1). $\gamma$-secretase is responsible for the processing of more than 70 transmembrane proteins involved in normal cellular processes, including regulation of cell fate, cell adhesion, migration, neurite outgrowth, synaptogenesis, calcium homeostasis, transport of membrane proteins, and cell signaling [6].

Briefly, amyloidogenic processing involves $\beta$ - and $\gamma$-secretases which induce $\mathrm{A} \beta$ production. Nonamyloidogenic processing mainly occurs at the cell surface, where $\alpha$-secretase is particularly enriched.

MicroRNAs (miRNAs) are 20- to 22-nucleotide RNAs that regulate gene expression the posttranscriptional level by binding with partial complementarity to the $3^{\prime}$ untranslated region (UTR) of target messenger RNAs (mRNAs), thereby leading to translational inhibition or degradation [7]. miRNAs are essential for neuronal development, function, and survival. Accumulating evidence in AD studies suggests that the alterations in the miRNA network could contribute to the risk for AD [8]. Some studies have revealed that those secretases mentioned above can be regulated by miRNAs. For examples, ADAM9 is the target of miR-126 [9,10]. ADAM10 is the target of miR-665 [11]. miR-24, miR-186, and miR-455 are regulators of NCT [12]. BACE1 is the target of miR-186 and miR-339 [13,14].

A few randomized clinical trials have demonstrated folate, administered in isolation or in combination with other B vitamins, may improve the memory or social function in older individuals with neuropsychiatric alterations [15-17]. In previous studies, we have found folate deficiency elevated hippocampal APP, PS1 and total A $\beta$ protein levels in APP/PS1 mice, and these rises were prevented by folic acid [18]. Furthermore, we have discovered folic acid deficiency can decrease several amyloid-associated miRNAs expression which may target APP and BACE1 [19]. PS1 and BACE1 are both important secretases involved in A $\beta$ production, so we hypothesized that folic acid may influence the expression of multiple secretases related to APP processing and A $\beta$ accumulation. Some other researches support our hypothesis. For example, deprivation of folate and vitamin E, coupled with dietary iron could increase PS1 expression, $\gamma$-secretase and A $\beta$ generation in ApoE-/- mice [20]. A combined folate, B12 and B6 dietary deficiency, would induce amyloid-beta overproduction and PS1/BACE up-regulation in TgCRND8 and 129Sv mice [21]. However, whether folic acid supplementation regulates secretases is still unknown. Therefore, in the present study, we further investigate the changes of $\mathrm{A} \beta 42$ and $\mathrm{A} \beta 40, \alpha-, \beta-$, and $\gamma$-secretase, as well as miRNAs, may target certain secretases in APP/PS1 mice brain tissue under folate deficiency and two levels of folic acid administration.

\section{Materials and Methods}

\subsection{Animals and Diet}

The Tianjin Medical University Animal Ethics Committee approved the experimental protocols in this study (Study number: TMUaMEC 2012016). Male mice with APPswe/PS1 $\Delta \mathrm{E} 9$ mutations (APP/PS1), backcrossed to C57B16/J, were obtained from the Chinese Academy of Medical Sciences Institute of Laboratory.

After genotyping, the AD transgenic mice were maintained on the control diet until the age of seven months and then were assigned in equal numbers to four groups: (1) folate-deficient diet plus daily gavage with water (deficiency); (2) control diet (normal folic acid content) plus daily gavage 
with water (control); (3) control diet plus daily gavage with $120 \mu \mathrm{g} / \mathrm{kg}$ folic acid (120 $\mu \mathrm{g} / \mathrm{kg})$; and (4) control diet plus daily gavage with $600 \mu \mathrm{g} / \mathrm{kg}$ folic acid $(600 \mu \mathrm{g} / \mathrm{kg})$.

The folate-deficient diet (containing folic acid $0.2 \mathrm{mg} / \mathrm{kg}$ diet) and the control diet (folic acid $2.1 \mathrm{mg} / \mathrm{kg}$ diet) were purchased from TestDiet (St. Louis, MO, USA). Thus, the average folic acid intake level for the four groups are $1 \mu \mathrm{g} /$ day, $10.5 \mu \mathrm{g} /$ day, $15.3 \mu \mathrm{g} /$ day, and $34.5 \mu \mathrm{g} /$ day, respectively.

All mice received food and drinking water ad libitum. Diets were treated for eight weeks. At the conclusion of the experiment, the mice were anesthetized by intraperitoneal injection of $7 \%$ chloral hydrate $(5 \mathrm{~mL} / \mathrm{kg})$ and perfused transcardially with phosphate buffered saline (PBS).

Brains were removed, bisected in the sagittal plane, and stored at $-80{ }^{\circ} \mathrm{C}$. Left brain tissue was used for immunohistochemistry staining and right brain tissue was used for other assays, as described below.

\subsection{Serum Folate}

Serum folate levels were determined by using a competitive protein-binding assay with chemiluminescent detection in an automated chemiluminescence system (Immulite 1000; Siemens, Berlin, Germany) according to the manufacturer's instructions at the end of the eighth week. The automated chemiluminescence system would detect all types of folate, including folic acid, dihydrofolate, and tetrahydrofolate.

\subsection{Immunohistochemistry}

The brains were removed and post-fixed with $4 \%$ paraformaldehyde in $0.1 \mathrm{M}$ phosphate buffer (pH 7.4) at $4{ }^{\circ} \mathrm{C}$ overnight. The brains were coronally-cut into $4 \mu \mathrm{m}$-thick sections with a vibratome. Free-floating sections were incubated with $4 \%$ bovine serum albumin in PBS for $1 \mathrm{~h}$, then reacted with monoclonal anti- $\beta$-amyloid protein antibody (Bam10, 1:3000, Sigma Aldrich, A5213; St. Louis, $\mathrm{MO}, \mathrm{USA}$ ) at $4{ }^{\circ} \mathrm{C}$ overnight. The sections were washed with PBS and reacted with biotinylated secondary antibodies diluted 1:200 in PBS and visualized using ABC Elite kit (Vector Laboratories, Burlingame, CA, USA). The images were carried out using a microscope (Olympus, Tokyo, Japan) and the integrated optical densities (IOD) of the hippocampi were determined with Image-Pro Plus 6.0 (Media Cybernetics, Rockville, MD, USA, 2003).

\subsection{ELISA for A $\beta$ Quantification and Secretases Activity}

Levels of $A \beta 40$ and $A \beta 42$ in mice brain were determined with ELISA assay by using mouse $\beta$-Amyloid 40 and 42 ELISA kit (Invitrogen, Carlsbad, CA, USA). $\alpha$ - and $\beta$-secretase activities were measured by relevant kits according to the manufacturer's instructions ( $\mathrm{R}$ and D Systems). Optical density (OD) was read at $450 \mathrm{~nm}$ within $30 \mathrm{~min}$ on a microplate spectrophotometer (Denley Dragon Wellscan MK3) (Thermo Fisher Scientific, Vantaa, Finland). Concentrations were calculated according to the standard curve. The percentage of concentration in the control group was shown.

\subsection{Western Blot Analysis}

Protein expression of ADAM9, ADAM10, BACE1, PS1, and NCT in mice brain was assessed by Western blot analysis. Total protein was extracted from homogenized brains with extraction buffer. Protein concentrations in the supernatants were determined by BCA protein assay kit (Thermo Scientific, Vantaa, Finland), using bovine serum albumin as a standard. Equal amounts of protein were loaded in each well for sodium dodecyl sulfate $12 \%$ polyacrylamide gel electrophoresis and then the separated proteins were transferred to nitrocellulose membranes. The membranes were blocked with 5\% non-fat milk and incubated with primary antibodies (anti-ADAM9, 1:1000, CST; anti-ADAM10, Abcam; anti-BACE1, 1:1000, CST; anti-PS1, 1:1000, Abcam; anti-NCT, 1:1000, CST) overnight at $4{ }^{\circ} \mathrm{C}$. Membranes were rinsed three times with Tris-buffered saline with Tween 20 (TBST) before being incubated with horseradish peroxidase-conjugated secondary antibody (1:10,000 in TBST) for $2 \mathrm{~h}$ and detected by chemiluminescence. Quantitation of proteins was done by densitometric 
analysis using NIH Image software (version 1.61, National Institutes of Health, Bethesda, MD, USA, 1997). The intensity of each protein band was normalized to the respective actin band (anti- $\beta$-actin, 1:5000, Abcam).

\subsection{Real-Time PCR for $m R N A$ and miRNA Expression}

For mRNA detection, total RNA was extracted using TRIzol. First-strand cDNA was synthesized from $2 \mu \mathrm{g}$ total RNA by using MMLV reverse transcriptase. The $20 \mu \mathrm{L}$ reaction volume was incubated for $50 \mathrm{~min}$ at $42{ }^{\circ} \mathrm{C}, 5 \mathrm{~min}$ at $90{ }^{\circ} \mathrm{C}, 5 \mathrm{~min}$ at $5{ }^{\circ} \mathrm{C}$ and was then stored at $-20{ }^{\circ} \mathrm{C}$. Real-time PCR was performed using the LightCycler 490 SYBR Green I Master Kit (Roche, Mannheim, Germany). The $20 \mu \mathrm{L}$ PCR mixture included $10 \mu \mathrm{L}$ of PCR Master mix, $5 \mu \mathrm{L}$ of cDNA, $1 \mu \mathrm{L}$ of forward primer, $1 \mu \mathrm{L}$ of reverse primer, and $3 \mu \mathrm{L}$ of water. The reaction mixtures were incubated at $95^{\circ} \mathrm{C}$ for $5 \mathrm{~min}$, which was followed by 45 amplification cycles (denaturation, $95^{\circ} \mathrm{C}$ for $10 \mathrm{~s}$; annealing, $56{ }^{\circ} \mathrm{C}$ for ADAM9 and ADAM10, $59{ }^{\circ} \mathrm{C}$ for BACE1 and $63{ }^{\circ} \mathrm{C}$ for PS1 for $10 \mathrm{~s}$; extension, $72{ }^{\circ} \mathrm{C}$ for $10 \mathrm{~s}$ ). Primers were specific for ADAM9 (forward, GCTGTCTTGCCACAGACCCGGTATGTGGAG; reverse, TGGAATATTAAGAAGGCAGTTTCCTCCTTT), ADAM10 (forward, AGTAGTAATCCAAAGTTGC CG; reverse, GTGTCCCATTTGATAACTCTCTC), BACE1 (forward, AATGTGCCTGTGGTTGTAGTC; reverse, TTGAAGAAGCAGAGAGAGACAG), and PS1 (forward, GCCCCAGAGTAACTCAAGACA; reverse, CCGGGTATAGAAGCTGACTGA). The assay was performed using the Roche LightCycler 480 sequence detector (Roche). The expression of each gene was normalized to $\beta$-actin (forward, AATGTGTCCGTCGTGGATCT; reverse, GGTCCTCAGTGTAGCCCAAG) in order to calculate relative levels of transcripts.

For miRNA determination, total RNA was reverse-transcribed to cDNA using RNase Inhibitor (Epicentre, Madison, WI, USA), dNTP (HyTest Ltd., Turku, Finland), RT buffer, and RT primers (Invitrogen). The mixture was incubated at $16{ }^{\circ} \mathrm{C}$ for $30 \mathrm{~min}, 42^{\circ} \mathrm{C}$ for $40 \mathrm{~min}$, and $85^{\circ} \mathrm{C}$ for $5 \mathrm{~min}$ to generate a library of miRNA cDNAs. U6 is used as an internal control for normalization. Real-time PCR was subsequently performed using an ABI PRISM7900 system (Applied Biosystems, Foster City, CA, USA) according to a standardized protocol. The reactions were incubated at $95{ }^{\circ} \mathrm{C}$ for $10 \mathrm{~min}$, followed by 40 cycles at an interval of $10 \mathrm{~s}$ at $95^{\circ} \mathrm{C}$ and an interval of $60 \mathrm{~s}$ at $60^{\circ} \mathrm{C}$. Data were analyzed by $2^{-\Delta \Delta C T}$.

\subsection{Statistical Analysis}

Results were expressed as mean \pm S.D. and analyzed using the SPSS 13.0 software package (SPSS Inc., Chicago, IL, USA, 2004). Data were analyzed by a one-way ANOVA followed by a Student-Newman-Keuls test. $p$ values $<0.05$ were considered to be statistically significant.

\section{Results}

\subsection{Folic Acid Reduces Total A $\beta$ Deposition and A 342 Protein Level, Increases Serum Folate Level}

The aim of this study was to determine the effects of folate deficiency and supplementation on AD-like pathology in APP/PS1 mice when daily treatment begun at seven months of age, when visible $\mathrm{A} \beta$ deposition may begin to be detected in this mouse model.

Immunohistochemical analysis showed that the accumulated $A \beta$ levels in brain tissue were higher in the deficiency group and lower in two folic acid supplementation groups than that in the control group $(\mathrm{F}[3,20]=10.16, p<0.05$; Figure 1A,B).

ELISA test results demonstrated that, compared to the control group, the levels of $A \beta 42$ deposits in the brain in the deficiency group was significantly higher, the $A \beta 42$ deposits in both two folic acid administration group were lower $(F[3,20]=60.21, p<0.05$; Figure $1 C)$. At the same time, we did not find a difference in $\mathrm{A} \beta 40$ accumulation in all $\mathrm{AD}$ groups $(\mathrm{F}[3,20]=1.031, p>0.05$; Figure $1 \mathrm{D})$.

Serum folate was detected at the end of eighth week. Compared to the control group, a folate deficient diet caused lower serum folate, and folic acid supplementation increased serum folate 
significantly $(\mathrm{F}[3,20]=66.01, p<0.05$; Figure $1 \mathrm{E})$. However, no significant difference in serum folate was shown between the $600 \mu \mathrm{g} / \mathrm{kg}$ and $120 \mu \mathrm{g} / \mathrm{kg}$ groups.
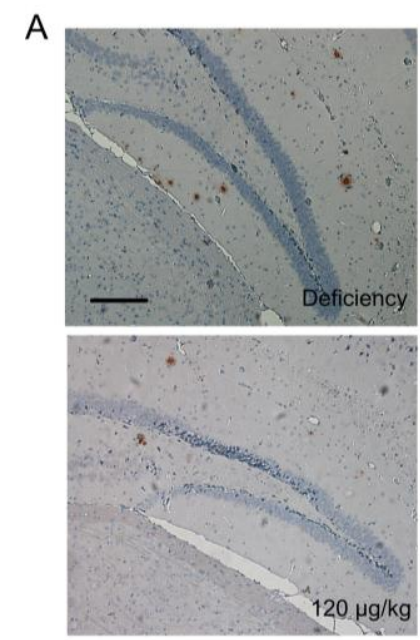
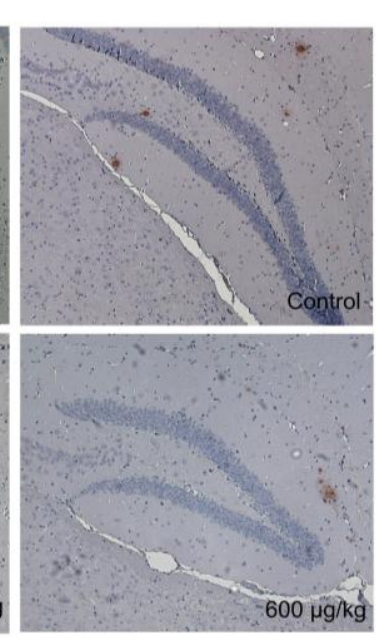
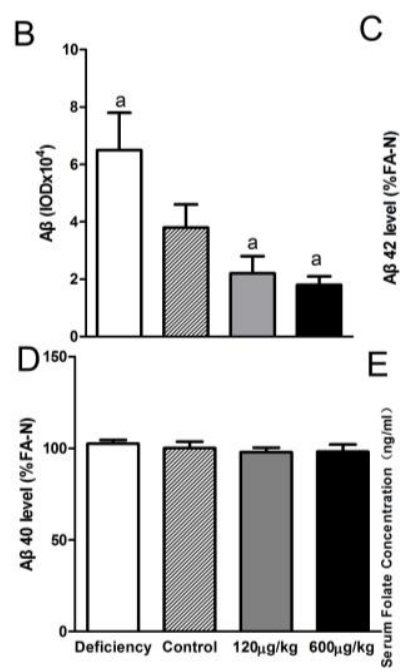

C
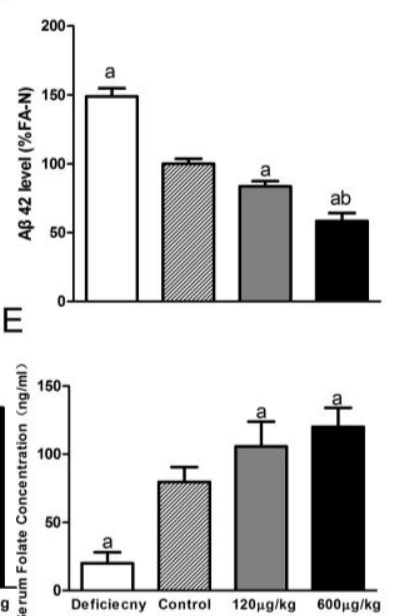

Figure 1. Folate reduced hippocampal amyloid plaque loads in APP/PS1 (amyloid precursor protein)/(presenilin 1) mice. With bam-10 immunohistochemical staining following the administration, compared with the control group, the deposition of $A \beta$ was significantly decreased in both $120 \mu \mathrm{g} / \mathrm{kg}$ and $600 \mu \mathrm{g} / \mathrm{kg}$ groups (A,B); scale bar $=100 \mu \mathrm{m}$. Enzyme-linked immuno sorbent assay (ELISA) was used to measure $A \beta$ levels in brain tissues. Compared with the control group, folic acid administration decreased A $\beta 42$ deposition, but not A $\beta 40$ (C,D). The A $\beta 42$ level was further decreased in the $600 \mu \mathrm{g} / \mathrm{kg}$ group compared to the $120 \mu \mathrm{g} / \mathrm{kg}$ group. After eight weeks, the folate deficiency diet reduced serum folate. Folic acid administration increased serum folate compared with the control group (E). The data were expressed as means \pm SD values, $n=6$ animals/group. a: $p<0.05$ versus the Control group; $\mathrm{b}: p<0.05$ versus the $120 \mu \mathrm{g} / \mathrm{kg}$ group.

\subsection{Folic Acid Increases ADAM9/ADAM10 Expression and $\alpha$-Secretase Activity}

As shown in Figure 2A-C, there was significant difference between four groups for ADAM9 expression $(\mathrm{F}[3,20]=9.098, p<0.05$ for mRNA, $\mathrm{F}[3,20]=31.4, p<0.05$ for protein). Compared to the control group the expression of ADAM9 mRNA and protein significantly decreased in the deficiency group, and increased in both the $120 \mu \mathrm{g} / \mathrm{kg}$ and $600 \mu \mathrm{g} / \mathrm{kg}$ groups. There was no difference between those two administration groups.

Similarly, folate deficiency and supplementation influenced the expression of ADAM10 $(\mathrm{F}[3,20]=$ $10.72, p<0.05$ for mRNA, F[3,20] = 9.348, $p<0.05$ for protein; Figure 2D-F). The ADAM10 mRNA and protein expression decreased in the deficiency group and increased in the $120 \mu \mathrm{g} / \mathrm{kg}$ group compared to the control group. However, the expression of ADAM10 in $600 \mu \mathrm{g} / \mathrm{kg}$ group was not up-regulated.

Total $\alpha$-secretase activity was further determined by ELISA. Results showed folic acid deficiency decreased $\alpha$-secretase activity and folic acid supplementation increased $\alpha$-secretase activity compared to the control group $(F[3,20]=12.11, p<0.05$; Figure $2 \mathrm{G})$.

\subsection{Folic Acid Inhibited BACE1 Expression and Activity}

Compared to the control group, the mRNA/protein expression level and the activity of BACE1 increased significantly in the deficiency group and decreased in both folic acid supplementation groups $(\mathrm{F}[3,20]=24.06, p<0.05$ for mRNA, $\mathrm{F}[3,20]=8.917, p<0.05$ for protein, $\mathrm{F}[3,20]=50.62, p<0.05$ for activity; Figure 3). There was no difference for BACE1 expression levels and its activity between the $120 \mu \mathrm{g} / \mathrm{kg}$ and $600 \mu \mathrm{g} / \mathrm{kg}$ group. 
A

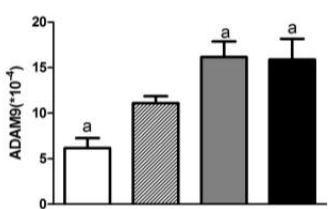

B

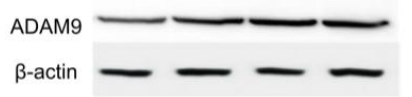

C

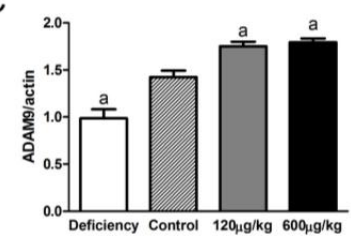

D

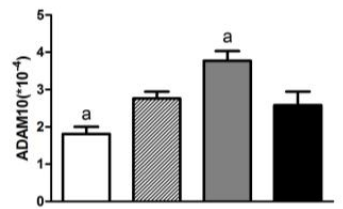

E

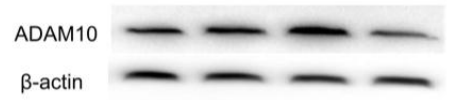

F

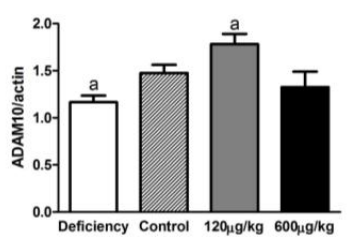

G

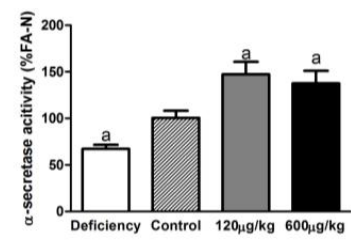

Figure 2. Folate stimulated ADAM9 and ADAM10 expression in APP/PS1 mice. The mRNA/protein levels of ADAM9 and ADAM10 in the brains of APP/PS1 mice were detected by qRT-PCR/Western blot analysis. Representative immunoblotting images of ADAM9 and ADAM10 are shown. Quantitative analysis revealed that the $120 \mu \mathrm{g} / \mathrm{kg}$ folic acid treatment led to up-regulation of ADAM9 (A-C) and ADAM10 (D-F). Folate deficiency led to down-regulation of ADAM9 and ADAM10. The $600 \mu \mathrm{g} / \mathrm{kg}$ folic acid treatment only up-regulated ADAM9, but did not change ADAM10 level; total $\alpha$-secretase activity was reduced in the deficiency group and was increased in both $120 \mu \mathrm{g} / \mathrm{kg}$ and $600 \mu \mathrm{g} / \mathrm{kg}$ groups $(\mathbf{G})$. The data were expressed as means \pm SD values, $n=6$ animals/group. a: $p<0.05$ versus the control group.

A

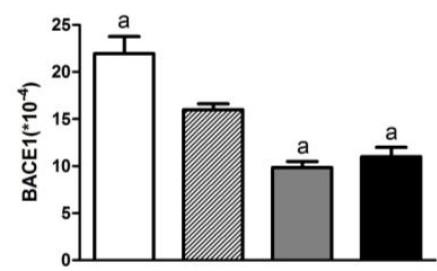

B

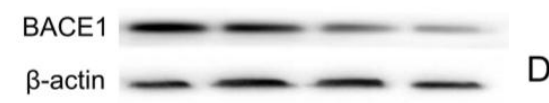

C
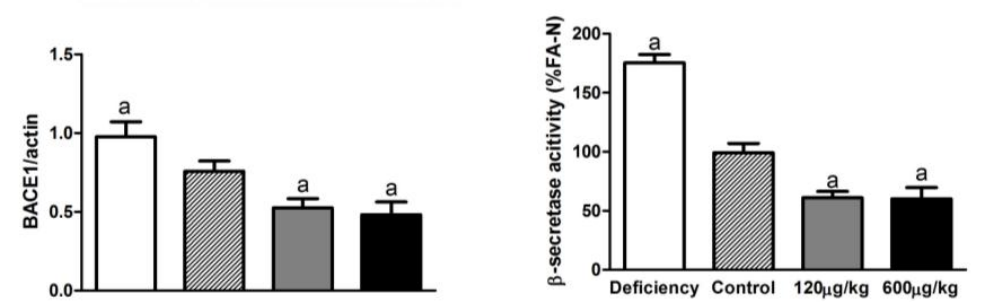

Figure 3. Folate inhibited BACE1 expression in APP/PS1 mice. BACE1 mRNAs and proteins in the brains of APP/PS1 mice were evaluated by qRT-PCR and Western blot analysis. The $\beta$-secretase activity was determined by ELISA. Representative bands and quantitative analysis revealed that folic acid treatment led to down-regulation of mRNA (A) and protein $(\mathbf{B}, \mathbf{C})$ expression of BACE1 and its activity (D). Folate deficiency led to up-regulation of BACE1 expression and activity. The data were expressed as means \pm SD values, $n=6$ animals/group. a: $p<0.05$ versus the control group. 


\subsection{Folic Acid Influenced PS1 Expression but Not NCT Level}

Compared to the control group, PS1 mRNA and protein levels increased in the deficiency group and decreased in the two supplementation groups $(\mathrm{F}[3,20]=21.49, p<0.05$ for $\mathrm{mRNA}, \mathrm{F}[3,20]=34.23$, $p<0.05$ for protein; Figure 4A-C). No significant difference was found between the $120 \mu \mathrm{g} / \mathrm{kg}$ and $600 \mu \mathrm{g} / \mathrm{kg}$ groups. No significant difference showed in all groups for NCT protein $(\mathrm{F}[3,20]=1.940$, $p>0.05$; Figure 4D,E).

A

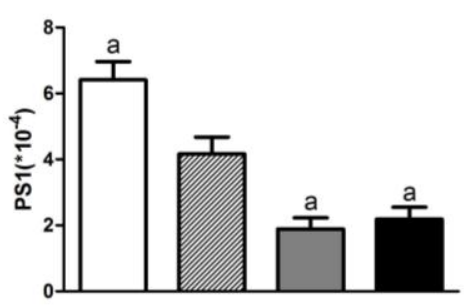

B

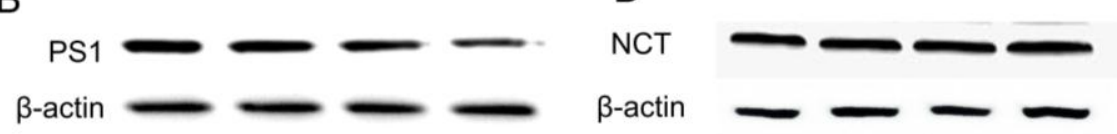

C

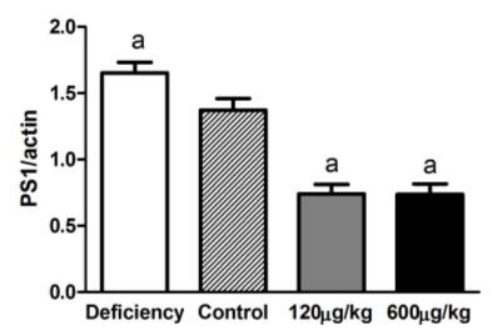

E

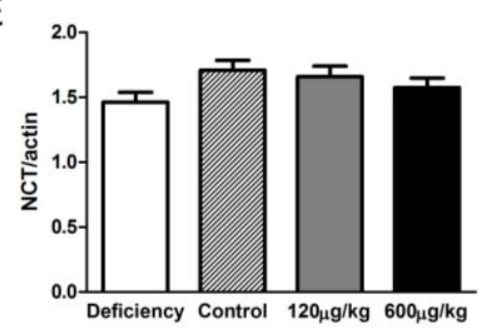

Figure 4. Folate inhibited PS1 expression, but not NCT (nicastrin), in APP/PS1 mice. PS1 mRNAs and proteins in the brains of APP/PS1 mice were determined by qRT-PCR and Western blot analysis. Folic acid treatment inhibited PS1 mRNA and protein expression. Folate deficiency led to up-regulation of PS1. No difference in PS1 expression was showed between $120 \mu \mathrm{g} / \mathrm{kg}$ and $600 \mu \mathrm{g} / \mathrm{kg}$ groups (A-C); However, Western blot analysis revealed that folic acid did not change NCT protein levels (D,E). The data were expressed as means $\pm \mathrm{SD}$ values, $n=6$ animals/group. a: $p<0.05$ versus the Control group.

\subsection{Folic Acid Regulated miRNAs Related to ADAM9 and BACE1}

miR-126-3p has already been identified as a miRNA which targets ADAM9 and can be regulated by DNA methyltransferases (DNMTs). miR-339-5p possibly target the seed same region on 3'-UTR of BACE1. In our study, miR-126-3p was up-regulated in the deficiency group and was down-regulated in both the $120 \mu \mathrm{g} / \mathrm{kg}$ and $600 \mu \mathrm{g} / \mathrm{kg}$ groups compared to the control group $(\mathrm{F}[3,20]=84.41$, $p<0.05$; Figure 5A). On the contrary, miR-339-5p was down-regulated in the deficiency group and was up-regulated in both $120 \mu \mathrm{g} / \mathrm{kg}$ and $600 \mu \mathrm{g} / \mathrm{kg}$ groups compared to the control group $(F[3,20]=138.1, p<0.05$; Figure 5B). No significant difference was observed between the $120 \mu \mathrm{g} / \mathrm{kg}$ and $600 \mu \mathrm{g} / \mathrm{kg}$ groups. 
A

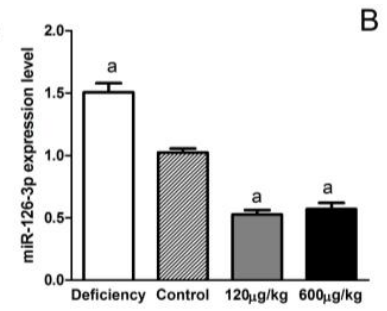

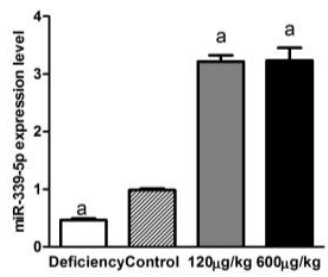

C

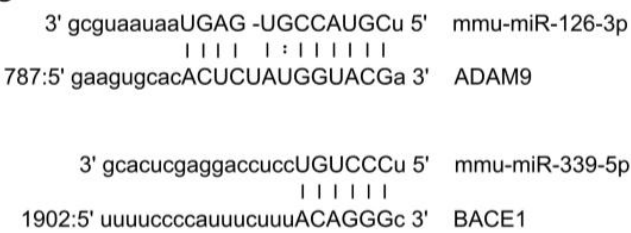

Figure 5. Folate regulated miR-126-3p and miR-339-5p expression in APP/PS1 mice brains. Two miRNA expression levels in the brains of APP/PS1 mice were confirmed by qRT-PCR. (A) miR-126-3p was expressed at lower level in both $120 \mu \mathrm{g} / \mathrm{kg}$ and $600 \mu \mathrm{g} / \mathrm{kg}$ groups, it was expressed at higher levels in the deficiency group compared to the control group; (B) miR-339-5p was expressed at higher level in both the $120 \mu \mathrm{g} / \mathrm{kg}$ and $600 \mu \mathrm{g} / \mathrm{kg}$ groups, it was expressed at lower level in the deficiency group compared to the control group; and (C) predicted miR-126-3p and miR-339-5p target sites in the $3^{\prime}$-UTR of ADAM9 or BACE1. Schematic representation of base pair matching between miRNAs and the 3-UTR of ADAM 9 and BACE1. The seed region of the miRNAs is indicated. The data were expressed as means \pm SD values, $n=6$ animals/group. a: $p<0.05$ versus the control group.

\section{Discussion}

Our previous studies have observed the effects of folic acid on elderly people with mild cognitive impairment, animal, and cell models of AD. Those results showed a beneficial effect from folic acid supplementation on cognitive functioning in later life [22]. It was also demonstrated that folic acid may modify $A \beta$ accumulation in vivo $[18,20]$ and in vitro [23-25]. In the present study, we investigated whether $\alpha-, \beta-$, and $\gamma$-secretase are all involved the inhibition effect of folic acid on $A \beta$ accumulation.

We have demonstrated folic acid deficiency increased A $\beta 42$ but not A $\beta 40$ in APP/PS1 mice brain [19]. Moreover, the present study revealed that folic acid supplementation still decreased A $\beta 42$ compared to $A \beta 40$. Meanwhile, serum folate showed a dose-dependent trend in those four groups. $A \beta 42$ is more amyloidogenic than $A \beta 40$, and is deposited earlier than $A \beta 40$ in the brain parenchyma in $A D$ patients [26]. A $\beta 42$ is the major isoform in the amyloid plaque in the brain of AD [27]. Since A $\beta 42$ is relatively insoluble in the interstitial fluid and is prone to parenchymal deposition, whereas $A \beta 40$ is more soluble and less prone to parenchymal deposition [28] might constitute the possible reason by which folic acid decreased $A \beta 42$, and not $A \beta 40$, in AD mice brains.

Two major pathways are involved in APP metabolism, one non-amyloidogenic and one amyloidogenic [29]. In the non-amyloidogenic pathway, APP is cleaved by $\alpha$-secretase and releases sAPP $\alpha$ and CTF- $\alpha$. $\gamma$-secretase cleaves CTF- $\alpha$ to produce $\mathrm{p} 3$ and AICD [30]. Our present work showed that folic acid increased $\alpha$-secretase activity which itself was achieved by up-regulating the expression of the ADAM9 and ADAM10 mRNA and protein.

In the amyloidogenic pathway, APP is first hydrolyzed by BACE1 and generates sAPP $\beta$ and CTF- $\beta$. $\gamma$-secretase further cleaves CTF- $\beta$ to release AICD and A $\beta$, which aggregates to form amyloid plaques [31]. BACE inhibition has been proposed to decrease the amount of APP processed into $\mathrm{A} \beta$, and shunt APP to the $\alpha$-secretase pathway. BACE1 is considered as an attractive drug target for reducing cerebral levels of $A \beta$ for the treatment or prevention of $A D[32,33]$. Our study indicated that folic acid significantly decreased BACE1 mRNA and protein expression, suggesting that folic acid may be a BACE1 inhibitor which results in higher metabolism of APP through non-amyloidogenic pathway and reduction of $A \beta$ generation.

Reports document that $\gamma$-secretase has been considered as a multi-subunit aspartyl protease that cleaves APP and has proved to be a highly tractable target for AD drug treatment [34]. Our study showed that folic acid treatment could modify PS1, which is one of the subunits of $\gamma$-secretase. However, NCT expression was not regulated by folic acid in our results. $\gamma$-secretase activity is dependent on the interaction with all four essential $\gamma$-secretase components. Our study did not find enough evidence to suggest folic acid influencing $\gamma$-secretase activity. 
Several studies have revealed certain APP secretases can be modified by miRNAs [35,36]. Since folic acid regulated ADAM9 significantly in the present study, and ADAM9 has been demonstrated functioning as a direct target of miR-126 [37], we determined miR-126-3p expression by real-time PCR and found miR-126-3p was repressed by folic acid treatment. Epigenetic modulation of the miR-126-3p has been recently demonstrated $[9,37]$.

Folate is required for one-carbon metabolism involving the transfer and utilization of one-carbon units in essential pathways. One-carbon metabolism is essential for de novo purine and thymidylate synthesis and for remethylation of homocysteine to methionine, which can then be adenosinylated to form the universal methyl donor SAM. One-carbon metabolism was also related to AD-like hallmarks (increased A $\beta$ production) [21,38]. Previous studies have indicated that in neural cells or AD mice, folic acid supplement leads to higher availability of SAM and activities of DNA methyltransferases (DNMTs) [24,39], which are required for cellular methylation reactions. Therefore, altered miRNAs expression in present study may be related to the changing of methyl donor pool, along with increasing DNA methylation by folic acid administration.

However, miR-339-5p expression showed a reverse trend compared to miR-126-3p. In a previous study we have revealed folic acid deficiency down-regulated miR-339-5p, which targets BACE1 [19]. In the current study, we demonstrated folic acid supplementation could up-regulate miR-339-5p and down-regulate BACE1 expression, which can further confirm the relationship between folic acid, miR-339-5p and BACE1. Since folic acid showed different effect on miRNAs which target different secretase, the underlying regulation mechanism of folic acid on miRNAs needs further investigation.

\section{Conclusions}

Our findings suggested that folic acid reduced A $\beta 42$ content in APP/PS1 mice brains. Furthermore, $\beta$-secretase decreased significantly, and different subtypes or components of $\alpha$-secretase (particularly ADAM9 and ADAM10) significantly increased. miRNAs which target ADAM9 and BACE1 may involve in the regulation effect of folic acid on those certain secretases.

Acknowledgments: This research was supported by grants from the National Natural Science Foundation of China (number 81202200, 81130053).

Author Contributions: All authors had full access to all data in this study and take responsibility for integrity of the data and accuracy of the data analysis. Study concept and design: Tian Tian and Huan Liu; Acquisition data: Tian Tian and Dong Bai; Analysis and interpretation data: Wen Li; Drafting of the manuscript: Tian Tian and Huan Liu; Critical revision of the manuscript for important intellectual content: Huan Liu; Obtained funding and study supervision: Huan Liu and Guo-Wei Huang.

Conflicts of Interest: The authors declare no conflict of interest.

\section{References}

1. Masters, C.L.; Simms, G.; Weinman, N.A.; Multhaup, G.; McDonald, B.L.; Beyreuther, K. Amyloid plaque core protein in Alzheimer disease and Downsyndrome. Proc. Natl. Acad. Sci. USA 1985, 82, 4245-4249. [CrossRef] [PubMed]

2. Glenner, G.G.; Wong, C.W. Alzheimer's disease: Initial report of the purification and characterization of a novel cerebrovascular amyloid protein. Biochem. Biophys. Res. Commun. 1984, 120, 885-890. [CrossRef]

3. Abraham, J.N.; Kedracki, D.; Prado, E.; Gourmel, C.; Maroni, P.; Nardin, C. Effect of the Interaction of the amyloid $\beta$ (1-42) peptide with short single-stranded synthetic nucleotide sequences: Morphological characterization of the inhibition of fibrils formation and fibrils disassembly. Biomacromolecules 2014, 15, 253-258. [CrossRef] [PubMed]

4. Lammich, S.; Kojro, E.; Postina, R.; Gilbert, S.; Pfeiffer, R.; Jasionowski, M.; Haass, C.; Fahrenholz, F. Constitutive and regulated alpha-secretase cleavage of Alzheimer's amyloid precursor protein by a disintegrin metalloprotease. Proc. Natl. Acad. Sci. USA 1996, 96, 3922-3927. [CrossRef]

5. Murphy, M.P.; LeVine, H., 3rd. Alzheimer's disease and the amyloid-beta peptide. J. Alzheimers Dis. 2010, 19, 311-323. [PubMed] 
6. Pardossi-Piquard, R.; Checler, F. The physiology of the $\beta$-amyloid precursor protein intracellular domain AICD. J. Neurochem. 2012, 120, 109-124. [CrossRef] [PubMed]

7. Djuranovic, S.; Nahvi, A.; Green, R. A parsimonious model for gene regulation by miRNAs. Science 2011, 331, 550-553. [CrossRef] [PubMed]

8. Delay, C.; Mandemakers, W.; Hebert, S.S. MicroRNAs in Alzheimer's disease. Neurobiol. Dis. 2012, 46, 285-290. [CrossRef] [PubMed]

9. Liu, R.; Gu, J.; Jiang, P.; Zheng, Y.; Liu, X.; Jiang, X.; Huang, E.; Xiong, S.; Xu, F.; Liu, G.; et al. DNMT1-microRNA126 epigenetic circuit contributes to esophageal squamous cell carcinoma growth via ADAM9-EGFR-AKT signaling. Clin. Cancer Res. 2015, 15, 854-863. [CrossRef] [PubMed]

10. Wang, C.Z.; Yuan, P.; Li, Y. MiR-126 regulated breast cancer cell invasion by targeting ADAM9. Int. J. Clin. Exp. Pathol. 2015, 8, 6547-6553. [PubMed]

11. Wu, G.; Zheng, K.; Xia, S.; Wang, Y.; Meng, X.; Qin, X.; Cheng, Y. MicroRNA-655-3p functions as a tumor suppressor by regulating ADAM10 and $\beta$-catenin pathway in Hepatocellular Carcinoma. J. Exp. Clin. Cancer Res. 2016, 35, 89. [CrossRef] [PubMed]

12. Delay, C.; Dorval, V.; Fok, A.; Grenier-Boley, B.; Lambert, J.C.; Hsiung, G.Y.; Hébert, S.S. MicroRNAs targeting Nicastrin regulate $\mathrm{A} \beta$ production and are affected by target site polymorphisms. Front. Mol. Neurosci. 2014, 7, 67. [CrossRef] [PubMed]

13. Kim, J.; Yoon, H.; Chung, D.E.; Brown, J.L.; Belmonte, K.C.; Kim, J. miR-186 is decreased in aged brain and suppresses BACE1 expression. J. Neurochem. 2016, 137, 436-445. [CrossRef] [PubMed]

14. Long, J.M.; Ray, B.; Lahiri, D.K. MicroRNA-339-5p down-regulates protein expression of $\beta$-site amyloid precursor protein-cleaving enzyme 1 (BACE1) in human primary brain cultures and is reduced in brain tissue specimens of Alzheimer disease subjects. J. Biol. Chem. 2014, 289, 5184-5198. [CrossRef] [PubMed]

15. Connelly, P.J.; Prentice, N.P.; Cousland, G.; Bonham, J. A randomized double-blind placebo-controlled trial of folic acid supplementation of cholinesterase inhibitors in Alzheimer's disease. Int. J. Geriatr. Psychiatry 2008, 23, 155-160. [CrossRef] [PubMed]

16. Durga, J.; van Boxtel, M.P.; Schouten, E.G.; Kok, F.J.; Jolles, J.; Katan, M.B.; Verhoef, P. Effect of 3-year folic acid supplementation on cognitive function in older adults in the FACIT trial: A randomised, double blind, controlled trial. Lancet 2007, 369, 208-216. [CrossRef]

17. Walker, J.G.; Batterham, P.J.; Mackinnon, A.J.; Jorm, A.F.; Hickie, I.; Fenech, M.; Kljakovic, M.; Crisp, D.; Christensen, H. Oral folic acid and vitamin B-12 supplementation to prevent cognitive decline in community-dwelling older adults with depressive symptoms-the beyond ageing project: A randomized controlled trial. Am. J. Clin. Nutr. 2012, 95, 194-203. [CrossRef] [PubMed]

18. Li, W.; Liu, H.; Yu, M.; Zhang, X.; Zhang, M.; Wilson, J.X.; Huang, G. Folic acid administration inhibits amyloid $\beta$-peptide accumulation in APP/PS1 transgenic mice. J. Nutr. Biochem. 2015, 26, 883-891. [CrossRef] [PubMed]

19. Liu, H.; Tian, T.; Qin, S.; Li, W.; Zhang, X.; Wang, X.; Gao, Y.; Huang, G. Folic acid deficiency enhances abeta accumulation in APP/PS1 mice brain and decreases amyloid-associated miRNAs expression. J. Nutr. Biochem. 2015, 26, 1502-1508. [CrossRef] [PubMed]

20. Chan, A.; Tchantchou, F.; Rogers, E.J.; Shea, T.B. Dietary deficiency increases presenilin expression, gamma-secretase activity, and Abeta levels: Potentiation by ApoE genotype and alleviation by $S$-adenosyl methionine. J. Neurochem. 2009, 110, 831-836. [CrossRef] [PubMed]

21. Fuso, A.; Nicolia, V.; Cavallaro, R.A.; Ricceri, L.; D’Anselmi, F.; Coluccia, P.; Calamandrei, G.; Scarpa, S. B-vitamin deprivation induces hyperhomocysteinemia and brain $S$-adenosylhomocysteine, depletes brain $S$-adenosylmethionine, and enhances PS1 and BACE expression and amyloid-beta deposition in mice. Mol. Cell. Neurosci. 2008, 37, 731-746. [CrossRef] [PubMed]

22. Ma, F.; Wu, T.; Zhao, J.; Han, F.; Marseglia, A.; Liu, H.; Huang, G. Effects of 6-month folic acid supplementation on cognitive function and blood biomarkers in mild cognitive impairment: A randomized controlled trial in China. J. Gerontol. A Biol. Sci. Med. Sci. 2015. [CrossRef] [PubMed]

23. Li, W.; Jiang, M.; Xiao, Y.; Zhang, X.; Cui, S.; Huang, G. Folic acid inhibits tau phosphorylation through regulation of PP2A methylation in SH-SY5Y cells. J. Nutr. Health Aging 2015, 19, 123-129. [CrossRef] [PubMed] 
24. Liu, H.; Li, W.; Zhao, S.; Zhang, X.; Zhang, M.; Xiao, Y.; Wilson, J.X.; Huang, G. Folic acid attenuates the effects of amyloid $\beta$ oligomers on DNA methylation in neuronal cells. Eur. J. Nutr. 2015, 55, 1849-1862. [CrossRef] [PubMed]

25. Li, W.; Jiang, M.; Zhao, S.; Liu, H.; Zhang, X.; Wilson, J.X.; Huang, G. Folic Acid Inhibits Amyloid $\beta$-Peptide Production through Modulating DNA Methyltransferase Activity in N2a-APP Cells. Int. J. Mol. Sci. 2015, 16, 25002-25013. [CrossRef] [PubMed]

26. Scheltens, P.; Blennow, K.; Breteler, M.M.; de Strooper, B.; Frisoni, G.B.; Salloway, S.; Van der Flier, W.M. Alzheimer's disease. Lancet 2016, 388, 505-517. [CrossRef]

27. Greenberg, S.M.; Gurol, M.E.; Rosand, J.; Smith, E.E. Amyloid angiopathy-related vascular cognitive impairment. Stroke 2004, 35, 2616-2619. [CrossRef] [PubMed]

28. Qiu, T.; Liu, Q.; Chen, Y.X.; Zhao, Y.F.; Li, Y.M. A $\beta 42$ and A $\beta 40$ : Similarities and differences. J. Pept. Sci. 2015, 21, 522-529. [CrossRef] [PubMed]

29. Buoso, E.; Lanni, C.; Schettini, G.; Govoni, S.; Racchi, M. beta-Amyloid precursor protein metabolism: Focus on the functions and degradation of its intracellular domain. Pharmacol. Res. 2010, 62, 308-317. [CrossRef] [PubMed]

30. Moir, R.D.; Tanzi, R.E. Lrp-mediated clearance of abeta is inhibited by kpi-containing isoforms of app. Curr. Alzheimer Res. 2005, 2, 269-273. [CrossRef] [PubMed]

31. Agostinho, P.; Pliássova, A.; Oliveira, C.R.; Cunha, R.A. Localization and Trafficking of Amyloid- $\beta$ Protein Precursor and Secretases: Impact on Alzheimer's Disease. J. Alzheimers Dis. 2015, 45, 329-347. [PubMed]

32. Devi, L.; Tang, J.; Ohno, M. Beneficial effects of the $\beta$-secretase inhibitor GRL-8234 in 5XFAD Alzheimer's transgenic mice lessen during disease progression. Curr. Alzheimer Res. 2015, 12, 13-21. [CrossRef] [PubMed]

33. Yan, R.; Vassar, R. Targeting the $\beta$ secretase BACE1 for Alzheimer's disease therapy. Lancet Neurol. 2014, 13, 319-329. [CrossRef]

34. Wolfe, M.S. Inhibition and modulation of gamma-secretase for Alzheimer's disease. Neurotherapeutics 2008, 5, 391-398. [CrossRef] [PubMed]

35. Liu, C.G.; Wang, J.L.; Li, L.; Xue, L.X.; Zhang, Y.Q.; Wang, P.C. MicroRNA-135a and -200b, potential Biomarkers for Alzheimer's disease, regulate $\beta$ secretase and amyloid precursor protein. Brain Res. 2014, 1583, 55-64. [CrossRef] [PubMed]

36. Cheng, C.; Li, W.; Zhang, Z.; Yoshimura, S.; Hao, Q.; Zhang, C.; Wang, Z. MicroRNA-144 is regulated by activator protein-1 (AP-1) and decreases expression of Alzheimer disease-related a disintegrin and metalloprotease 10 (ADAM10). J. Biol. Chem. 2013, 288, 13748-13761. [CrossRef] [PubMed]

37. Andersen, M.; Trapani, D.; Ravn, J.; Sørensen, J.B.; Andersen, C.B.; Grauslund, M.; Santoni-Rugiu, E. Methylation-associated Silencing of microRNA-126 and its Host Gene EGFL7 in Malignant Pleural Mesothelioma. Anticancer Res. 2015, 35, 6223-6229. [PubMed]

38. Fuso, A.; Scarpa, S. One-carbon metabolism and Alzheimer's disease: Is it all a methylation matter? Neurobiol. Aging 2011, 32, 1192-1195. [CrossRef] [PubMed]

39. Li, W.; Yu, M.; Luo, S.; Liu, H.; Gao, Y.; Wilson, J.X.; Huang, G. DNA methyltransferase mediates dose-dependent stimulation of neural stem cell proliferation by folate. J. Nutr. Biochem. 2013, 24, 1295-1301. [CrossRef] [PubMed]

(C) 2016 by the authors; licensee MDPI, Basel, Switzerland. This article is an open access article distributed under the terms and conditions of the Creative Commons Attribution (CC-BY) license (http://creativecommons.org/licenses/by/4.0/). 